\title{
Static consolidation of a renaissance palace by resins, pins and connecting rods
}

\author{
Antoniotto Guidobono Cavalchini, ${ }^{1}$ Martino Guidobono Cavalchini, ${ }^{2}$ Elena Poverello ${ }^{3}$ \\ ${ }^{1}$ Department of Health, Animal Science and Food Safety, Università degli Studi di Milano, Milano, \\ Italy; ${ }^{2}$ Architect; ${ }^{3}$ Engineer, Bossong S.p.A.
}

\begin{abstract}
The paper reports the results of a research on the static consolidation of an important XV century tower by Bramante belonging to an important monumental complex located in the Po Valley which was showing worrying structural conditions . The tower, $19 \mathrm{~m}$ high, very thin, lacking connections in the highest part, showed overturnings of the four façades not in plumb by over $150 \mathrm{~mm}$; Due to the presence of architectural terracotta elements, it was not possible to intervene on the external facades. This is why the authors decided to create a sort of hoop from inside using a $\mathrm{U}(120 \mathrm{~mm})$ steel profile fastened to the walls by means of steel pins anchored with epoxy resins. The pins ( 12 $\mathrm{mm}, 350 \mathrm{~mm}$ length) have been positioned at a distance of $50 \mathrm{~cm}$ inclined by $30^{\circ}$ alternatively downwards and upwards in order to get at minimum of $2+2$ courses of bricks. Then, by a series of steel tie rods it was possible to tie the opposite walls. Finally, triangular frames have been positioned on the 4 corners in order to avoid teething collapse in case of great stress. Before starting with the strengthening work, as described above, experimental tests, supported by the Bossong company, were conducted to verify tensile stress resistance of each pin. The tests studied different solutions in terms of diameter and anchoring material. The tensile tests, carried out by using a specific hydraulic puller equipped with a dynamometer and a displacement transducer, showed very high allowable loads, between 20 and $60 \mathrm{kN} /$ pin depending on the pin and fastening type. According to data obtained, the most suitable solution was chosen; it was also used in other parts of the castle. The behavior of the reinforced structure, which withstood the February 2012 earthquake without any problem demonstrated the validity of the proposed technique which is an interesting, non invasive solution for historical buildings.
\end{abstract}

Correspondence: Antoniotto Guidobono Cavalchini, Department of Health, Animal Science and Food Safety, Università degli Studi di Milano, Via Celoria 10, 20133, Milano, Italy.

E-mail: antoniotto.cavalchini@unimi.it

Key words: historical building restoration; anchoring means; static consolidation.

(C) Copyright A. Guidobono Cavalchini et al., 2013

Licensee PAGEPress, Italy

Journal of Agricultural Engineering 2013; XLIV(s2):e87

doi:10.4081/jae.2013.s2.e87

This article is distributed under the terms of the Creative Commons Attribution Noncommercial License (by-nc 3.0) which permits any noncommercial use, distribution, and reproduction in any medium, provided the original author(s) and source are credited.

\section{Introduction}

The work was carried out in the castle-palace, built around 1490, by a leading Milanese courtier, Bergonzo Botta, in Branduzzo (PV) on the right bank of the Po. Although there are no sure documents, Bramante is given credit for the palace, and in any case to his circle, which at the time worked in Milan and to whom, besides Amadeo, Botta had already tapped to build his own palace in Milan [1,2,3].

The Branduzzo complex is completely built with terracotta bricks produced locally. It is made up of two rectangular courts having a common quarter, of which one smaller so called noble, and one larger used for agricultural purposes. The former is closed on three sides by twostorey buildings,; the fourth side overlooks the Bramante palace. Four towers in the court corners complete the court. Of these the two shortest ones joint the three short bodies and are extremely simple, they date back to the middle of the 400s, while the two that joint the body of the palace are decidedly taller and stylistically homogenous with the same palace (Figures 1 and 2).

As for the one facing north (Figure 1), poor upkeep, structural modifications in the XVIII c., and time itself have caused severe settling. The object of this paper is in fact static consolidation.

The north tower, state (Figure 3): the 19-metre tower at its eaves leans on two sides, one to the side of the palace and the other to the bottom of the building, giving it significant strength. In section (Figure 3) we notice that from a continuous $0.60 \mathrm{~m}$ thickness to $12 \mathrm{~m}$, up to the first floor vault, the masonry decreases to just 0.40 . From $12 \mathrm{~m}$ up to the top the masonry is free without floors or other connecting elements. It's what gives it its slenderness. This could lead to bucking because at the top the walls are stressed by horizontal forces of the roof hip rafters. The main frame of the roof, is in fact made up of a roof truss from which four hip rafters set out resting on the arris creating a horizontal thrust. Furthermore, the roof truss, originally facing south-north, was subsequently (XIX c.) moved to the east-west axis facing west (towards the garden); here the masonry was weakened further due to a flue. In the XVIII c. new openings were made and balconies built in the north facade, modifying the original structure and its static balance.

For the above reasons as well as for time and lack of maintanance, the structure is in a precarious state resulting in toothing loss on the arris and out of plumb on all 4 facades. Thanks to the building that leans on the west facade up to $15 \mathrm{~m}$, the west façade shows modest settling signs the flue mentioned above notwithstanding. Out of plumb is mainly towards the outside, the greatest are along the boundary fascia at cornice level which is mostly decorative. In said fascia we noticed out of plumb 150, 180, $110 \mathrm{~mm}$ respectively in the South, East, and North facades.

Consolidation interventions: in such situation, in order to strengthen the structure and avoid further deterioration it was decided to carry out a reversible intervention resorting to:

- a hoop around the tower in order to contain settling towards the outside; 
- a network of tie-beams between opposite facades so as to create an intermediary joint capable of reducing the slenderness of the walls;

- joint tie-beams between hip-rafters on opposite ends so as to eliminate horizontal thrust.

As it was not possible to use a hoop from the outside, so as not to alterate the facade, we opted to intervene from the inside employing section irons anchored to the masonry using steel pins and mortar and/or epoxy.

\section{Materials and methods}

In order to test the anchors to be used in the project, extraction trials were carried out on different types of sample anchors.

Given the difficulties to carry out extraction trials on the structure itself and at the same time avoid weakening the masonry around the area to be consolidated, it was decided to run the tests at the base of the twin tower, easily done with the equipment used. The two towers are contemporary, with same-size bricks $(26 \times 13 \times 6,5)$ made in a special furnace specifically built locally so the structure of the two towers is anologous. Today, a patch on the outskirts of the complex still keeps its old name "campo furnasa", here while working the land one can still find objects made of terracotta. A mensiochronological trial analysis revealed no important differences between the bricks with which the various 14th c. structures (the object of this study) were built. On the contrary, behavioural differences have to be presumed and can be assessed with data made available from literature books in the masonrysection on the ground floor, were extraction trials were carried out, and the portion $+16 \mathrm{~m}$ where the consolidation intervention was made due to the different influence of the vertical load which burden the two areas. Nevertheless, the test results are of extreme importance for this intervention and for similar situations. The different tests are summarized in table 1, the test site is shown in Figure 4. For the research the behaviour of two different types of injected anchorage were tested: controlled injection anchorages with sock and mortar and anchorages with epoxy, even though project needs specifically the high number of joints to connect the profile in the hoop of the Bramante tower with perimetrical masonry, favoured, during application, the second type, above all for the smaller of the hole.

Once the perforations were made using a core boring machine, the steel bars were have been anchored with binders using the procedure indicated in table 1. Time was allowed for the mortar and resin to dry; subsequently extraction trials were carried out using a manually activated pierced piston oleodynamic cylinder extractor able to exert a maximum force of of $576 \mathrm{kN}$, measured by means of a pressure transducer applied to the hydraulic circuit. In relation to the applied load, movements were measured using a straight transducer potentiometer with a ball-like sounder having a resolution of $0.01 \mathrm{~mm}$ positioned on top of the steel bar. To read and record test data, an acquisition digital system, made up of a personal computer linked to an acquisition/conversion A/D (anologic/digital) electronic control unit, was used. Recording of instrument indications (load or pressure and movement) was carried out every 0.5 seconds. Figure 5 shows an outline of the trial equipment used.

\section{Results}

Figures 7 and 8 show the behavioral graphs of the different anchorage systems tested, while the main values are outlined in table 2 . As regards controlled injection anchorage with sock, the results are of great importance in the case of mortar type Hs cement-based mixture, where we reach linear field values higher than $100 \mathrm{kN}$ in both repetitions. Instead in the Ls theses, lime-based mixture, the values as always in linear field are decidedly lower around $35 \div 40 \mathrm{kN}$, with an ini-

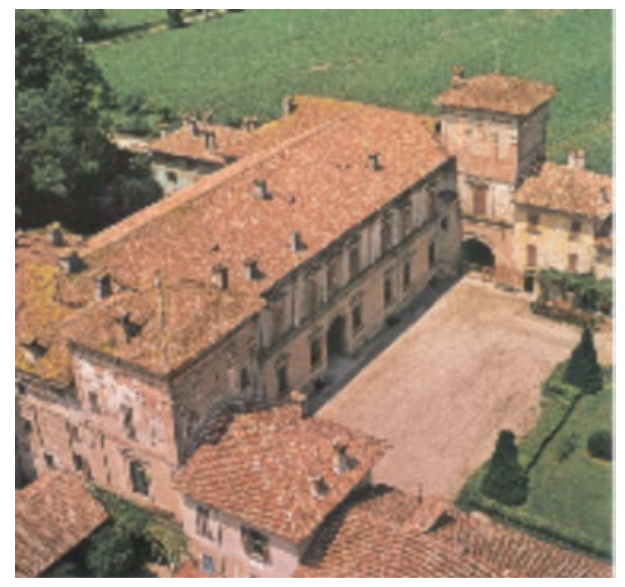

Figure 1. General view of Branduzzo palace.
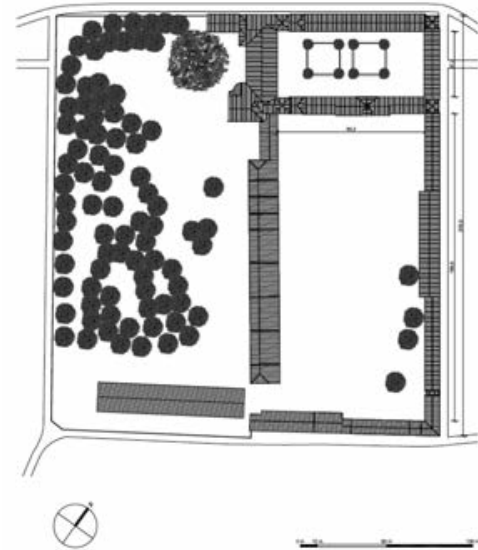

Figure 2. General plan of Branduzzo complex.

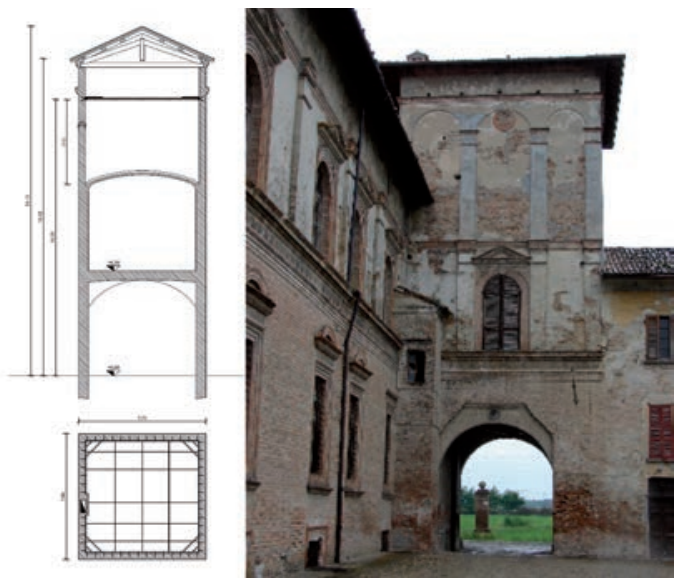

Figure 3. Above: vertical section of the tower; below: cross section and the structural interventions; right: the north tower. 
tial breaking of the substratum and subsequent unthreading of the anchorage bulb.

In the two these with resin anchorage, the E20 solution with a $20 \mathrm{~mm}$ diameter pin and anchorage length of $400 \mathrm{~mm}$ (surface adherence to the sustratum being $30144 \mathrm{~mm}^{2}$ ) reveal good results in both repitions : maximum peak load, is around $60 \div 70 \mathrm{kN}$.Peak values around $70 \mathrm{kN}$ are also reached with E12 with $12 \mathrm{~mm}$ diameter pins and $350 \mathrm{~mm}$ anchorage length (surface anchorage at substratum being $13188 \mathrm{~mm}^{2}$ ). This is true only in one of the two repitions since in the second one the maximum load is around $47 \mathrm{kN}$. With the same maximum load E12 theses movements were much more significant compared to the E20 theses (Table 2). Table 2 also shows rigidity $\mathrm{K}$ values and tension in keeping with what Algeri Poverello et al. found in similar trials carried out on anchorages with sock and mortar cement-based mixture (HS) and lime (LS) both in the laboratory and on site [5,7].Carefully analyzing the graphs (Figures 7 and 8) and taking into account the age of the bricks, only the linear loads were considered, or characterized by displacements 1 (mm): Using this approach the feasible loads are lower: HS.162,43=HS.255,16=90kN; LS.138,09=35kN; LS.246,69=45kN; E20.147,78=42kN; E20.2=66,4060kN; $\mathrm{E} 12.132,27=32 \mathrm{kN} ; \mathrm{E} 12.226,58=27 \mathrm{kN}$.

Consolidation intervention: thanks to the results, we proceeded to define and realize the above mentioned consolidation work. For the hoop a UPN 120 profile was chosen easy to place, perforate and capable of following the curvilinear profile of the brickwork, while guaranteeing good resistance to flexion in terms of $y(\mathrm{Wy}=11,1 \mathrm{~cm} 3)$. The section was fastened to the walls with 14 pins $12 \mathrm{~mm}$ (wall holes 14 -ideal anchorage length $350 \mathrm{~mm}$ ) using epoxy. Wheel-base between the pins is variable to avoid the perforations from falling in the joints between the single bricks, is circa $50 \mathrm{~cm}$. Then, by a series of steel tie rods it was possible to tie the opposite walls . Finally, triangular frames have been positioned on the 4 corners in order to avoid teething collapse in case of great stress (Figure 9). Cautiously taking into consideration a load of $10 \mathrm{kN} /$ pin determined by using a safety coefficient $=4$, the system should be able to resist lateral thrusts of $140 \mathrm{kN}$

\section{Conclusions}

The solution proposed was supported by on site tests which allowed us to reach a detailed definition of the best type of anchorage most suitable to the application: resistance and size of the anchorage, type of brickwork and geometry of the structural elements, these are the parameters on which the choice was based. By simply modifying one of
Table 1. Characteristics of the different anchoring systems tested

\begin{tabular}{|c|c|c|c|c|}
\hline Thesis & $\begin{array}{l}\text { Diameter of } \\
\text { the hole } \\
\text { (mm) }\end{array}$ & $\begin{array}{l}\text { Diameter of } \\
\text { the pin } \\
\text { (mm) }\end{array}$ & $\begin{array}{l}\text { Anchorage } \\
\text { system }\end{array}$ & $\begin{array}{l}\text { Lenght of } \\
\text { the anchorage } \\
(\mathrm{mm})\end{array}$ \\
\hline Hs & 62 & $\mathrm{~m}$ & $\begin{array}{l}\text { Controlled injecion } \\
\text { anchorage with sock and } \\
\text { nortar Bossong BCM Hs with } \\
\text { a cement basea }\end{array}$ & th \\
\hline Ls & 62 & 20 & $\begin{array}{c}\text { Controlled injecion } \\
\text { anchorage with sock } \\
\text { and mortar Bossong } \\
\text { BCM Ls with a lime base }\end{array}$ & 550 \\
\hline E20 & 24 & 20 & Epoxy anchorage Bossong & 400 \\
\hline E12 & 14 & 12 & Epoxy anchorage Bossong & 350 \\
\hline
\end{tabular}

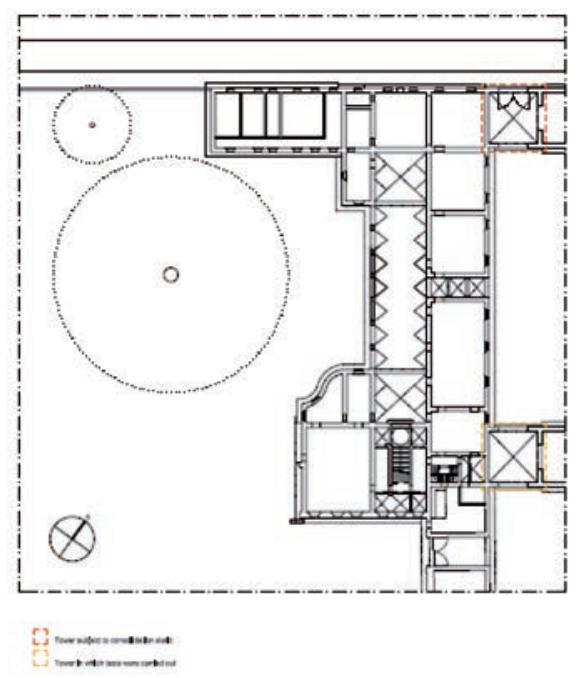

Figure 4. The test site and the tower to be consolidated.

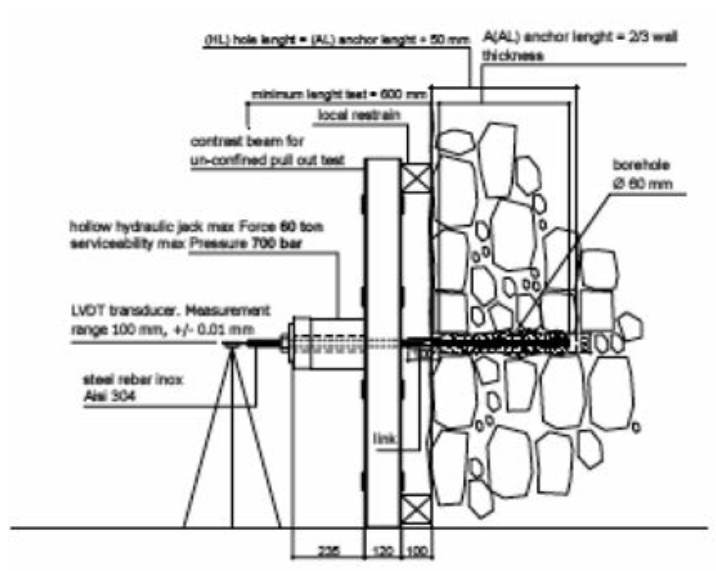

Figure 5. Trial equipment used.

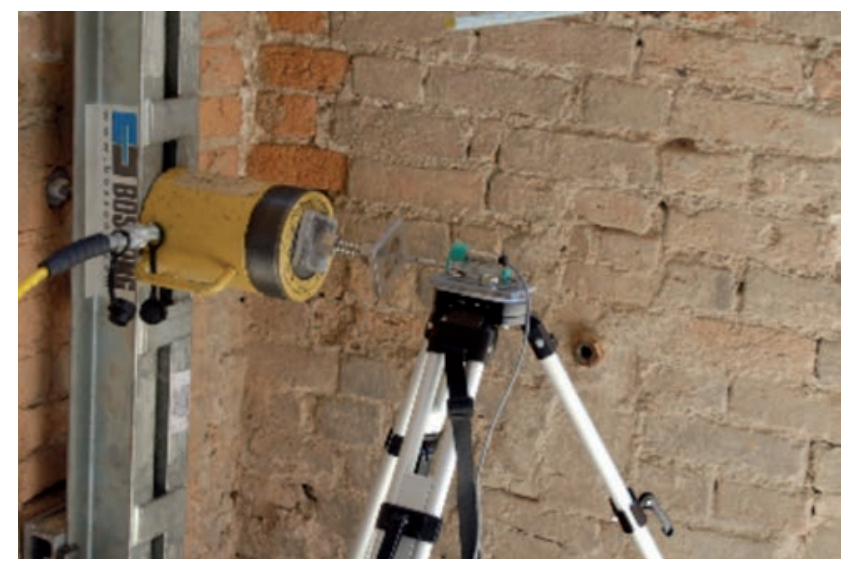

Figure 6.The equipment during the extraction trials. 
Table 2. Main data recorded in the tests.

\begin{tabular}{|c|c|c|c|c|c|c|c|c|c|c|c|c|}
\hline Test & $\begin{array}{c}F_{50 \%} \text { linear } \\
\text { value } \\
{[\mathrm{kN}]}\end{array}$ & $\begin{array}{c}F_{1} \\
\text { load at a } \\
\text { displace- } \\
\text { ment of } \\
1 \mathrm{~mm} \\
{[\mathrm{kN}]}\end{array}$ & $\begin{array}{c}\mathrm{F}_{\max } \\
\max \text { load } \\
{[\mathrm{kN}]}\end{array}$ & $\begin{array}{c}F_{\text {post }} \\
\text { final value } \\
\text { after the } \\
\text { peak } \\
{[\mathbf{k N}]}\end{array}$ & 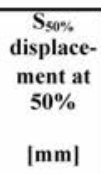 & 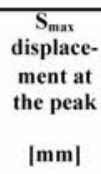 & $\begin{array}{c}\mathrm{K}_{\mathrm{s} 0 \%} \\
\text { fastening } \\
\text { stiffness at } \\
\mathbf{5 0 \%} \\
{[\mathrm{kN} / \mathrm{mm}]}\end{array}$ & $\tau_{\text {hole }} 50 \%$ & {$\left[\mathrm{~N} / \mathrm{mm}^{2}\right.$ ] } & {$\left[\mathrm{N} / \mathrm{mm}^{2}\right]$} & {$\left[\mathbf{N} / \mathrm{mm}^{2}\right]$} & Failure mode \\
\hline
\end{tabular}

\begin{tabular}{|c|c|c|c|c|c|c|c|c|c|c|c|c|}
\hline HS.1 & 70,93 & 62,43 & 141,85 & 114,44 & 1,33 & 4,98 & 53,33 & 0,73 & 2,26 & 1,46 & $\begin{array}{c}\text { masonry failure and } \\
\text { pull out of the bar } \\
\text { (loss of adherence } \\
\text { between bar and } \\
\text { grout) }\end{array}$ \\
\hline
\end{tabular}

\begin{tabular}{|c|c|c|c|c|c|c|c|c|c|c|c|c|}
\hline HS.2 & 64,17 & 55,16 & 128,34 & 111,43 & 1,19 & 4,60 & 53,93 & 0,66 & 2,04 & 1,32 & $\begin{array}{c}\text { masonry failure and } \\
\text { pull out of the bar } \\
\text { (loss of adherence } \\
\text { between bar and } \\
\text { grout) }\end{array}$ \\
\hline
\end{tabular}

\begin{tabular}{|c|c|c|c|c|c|c|c|c|c|c|c|c|}
\hline LS.1 & 44,69 & 38,09 & 89,38 & ..... & 1,48 & 22,70 & 30,20 & 0,46 & 1,42 & 0,92 & 2,85 & $\begin{array}{l}\text { masonry failure and } \\
\text { pull out of the } \\
\text { anchor (loss of } \\
\text { adherence between } \\
\text { grout and masonry }\end{array}$ \\
\hline LS. 2 & 40,28 & 46,69 & 80,56 & $\ldots$ & 0,68 & 17,89 & 59,23 & 0,41 & 1,28 & 0,83 & 2,57 & pull out of the bar \\
\hline$E 20.1$ & 21,26 & 47,78 & 62,52 & 30,09 & 0,27 & 2,29 & 115,78 & 0,71 & 0,85 & 2,07 & 2,49 & masonry failure \\
\hline E20.2 & 36,64 & 66,40 & 73,28 & 62,41 & 0,10 & 5,07 & 366,4 & 1,22 & 1,46 & 2,43 & 2,92 & masonry failure \\
\hline E12.1 & 42,28 & 32,27 & 84,56 & -.... & 1,49 & 13,31 & 28,37 & 2,75 & 3,21 & 5,50 & 6,41 & masonry failure \\
\hline E12.2 & 23,28 & 26,58 & 47,61 & 19,32 & 0,90 & 4,25 & 26,45 & 0,18 & 0,21 & 3,09 & 3,61 & masonry faiure \\
\hline
\end{tabular}

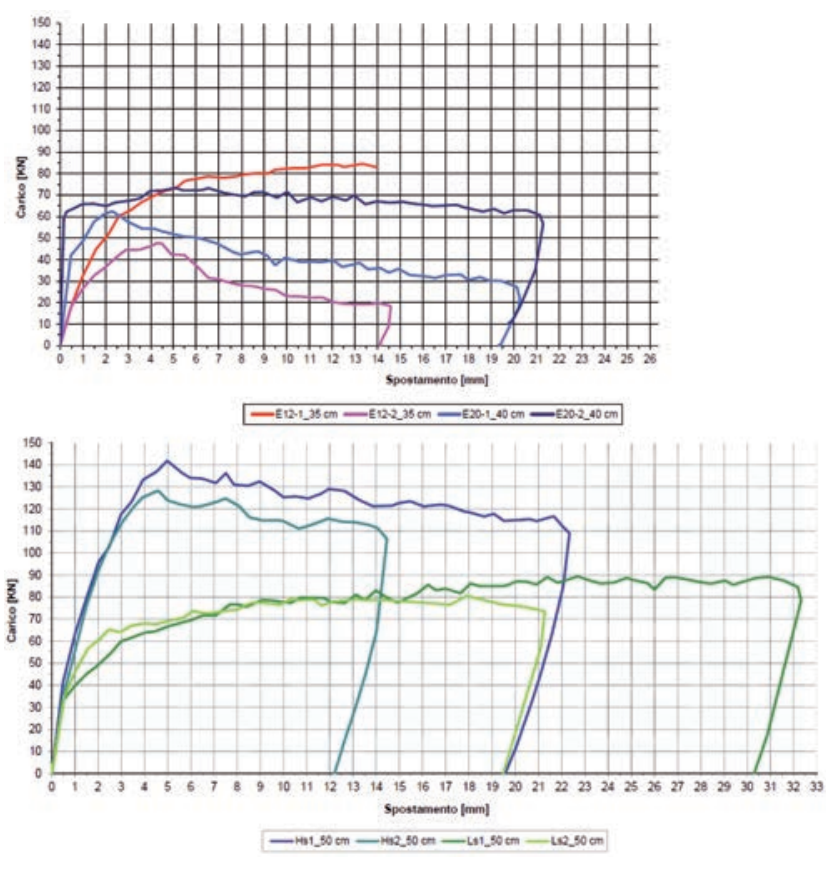

Figures 7 and 8 . Load=f(displacement) in the tested achoring solutions.

the parameters, for example the type of masonry, stone rather than brick, can change the surrounding conditions, thus the choice could be made for a different type of anchorage compared to the one chosen for the Bramante tower.

Globally speaking regardless of the type of anchorage used for the

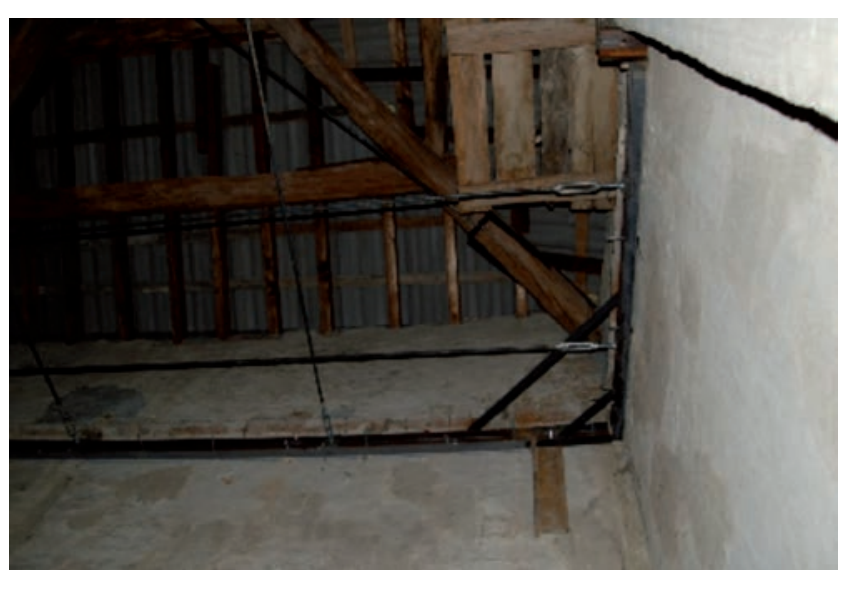

Figure 9. The loop created from inside: the $U$ profile fastened to the masonry by the anchored pins, the triangular frame at the corner and the steel tie rods are shown.

connection of the profile, the method used makes it possible to build an efficient containment of the tower walls, in order to create the boxshaped structure and efficacy of the walls to support horizontal thrusts that may occur during earthquakes. The metal elements bond the walls stressed orthogonally on its floor, impeding overturning. 


\section{References}

1) P.Merzagora a.a. 1992-93 "L'influsso del Bramante a Milano nell'architettura privata:il palazzo di Bergonzo Botta "degree diss. Politecnico di Milano, Faculty of Architecture.

2) E.Rossetti a.a. 2005-06" Residenze aristocratiche , spazi urbani e interventi principeschi nella Milano di Lodovico il Moro" Università degli Studi di Milano, Faculty of Phylosofy

3) L.Giordano 1978 Branduzzo in A.Peroni et al "Pavia architetture dell'età sforzesca"- Ist.bancario S.Paolo di Torino- Torino pp 231284

4) A.Falcone, V.Pracchi, E.Romoli "Indagini e consolidamento strutturale Palazzo Botta-Adorno Castelletto di Branduzzo", Scuola di Specializzazione in Restauro dei Monumenti a.a. 1993/'94 Politecnico di Milano

5) Felicetti R., Gattesco L., penetration test to study the mechanical responce of mortar in ancient masonry buildings in Materials and
Methods RILEM vol 31, june 1998 pp350-356

6) C. Algeri, E.Poverello,E. Giuriani, G.Plizzari 2010 "Experimental study on the injected anchors behaviour" in Structural Analysis of Historical Constructions Xianglin Gu and Xiaobin Song. Shanghai pp 423-428

7) C.Algeri, E.Poverello, 2010 "La ricerca sul comportamento degli ancoraggi iniettati nelle murature storiche in situ" Atti Convegno Ricerca e Innovazione nel consolidamento delle strutture in muratura in zona sismica. Ferrara- Salone internazionale del Restauro.

8) Algeri, E.Poverello,E. Giuriani, G.Plizzari 2010 "Prove sperimentali di estrazione di ancoraggi iniettati in murature storiche" Atti Convegno "Evoluzione nella sperimentazione per le costruzioni" Madrid 2010

9) L.Jurina 2007 Sperimentazione e didattica per la comprensione delle strutture storiche, "XXX Curset - Jornadas Internacionales sobre la intervencion en el patrimonio arquitectonico", Barcellona, 13 - 16 dicembre 2007. 